\title{
Analysis and characterization of cefixime by using IR, HPLC and gas chromatography
}

\author{
M. Prasada Rao ${ }^{1, *}$, B. Rama Rao ${ }^{2}$, M. Srikanth ${ }^{3}$ \\ ${ }^{1}$ Professor \& Principal, ${ }^{2}$ Assistant Professor, ${ }^{3}$ Associate Professor, ${ }^{1,2}$ Dept. of Pharmaceutical Analysis, ${ }^{3}$ Dept. of Parmacology, \\ M.A.M College of Pharmacy, Kesanupalli, Guntur DT, Andhra Pradesh, India
}

*Corresponding Author:

Email: prins2mam@gmail.com

\begin{abstract}
To develop a new, simple, sensitive, accurate, and economical analytical methods for the estimation of related compounds in Cefixime formulations. Validate the proposed methods in accordance with USP, EUROPE and ICH guidelines for the intended analytical application. Identify whether the given sample is Cefixime by IR spectroscopy and solubility test. To determine the wavenumber in cm-1 (reciprocal to wave length region) of given sample by Infrared Spectroscopy. To determine the moisture content present in the given sample of Cefixime by Karl Fischer method. Find out the assay and related substances (impurities) of given Cefixime by using the validated method with help of High performance Liquid Chromatography. Estimate the amount of Residual solvents by Gas Chromatography. The tests were performed as per the requirements of EUROPE monograph for Cefixime.
\end{abstract}

Keywords: Cefixime, IR, HPLC and gas chromatography.

\section{Introduction}

Cefixime: Cefixime is an orally absorbed third generation cephalosporin antibiotic that was approved by the U.S. Food and Drug Administration in 1997 for the treatment of mild to moderate bacterial infections.

\section{IUPAC Name:}

$\left(6^{\wedge}, 7^{\wedge}\right)-7-\{[2-(2-$ amino-1, 3-thiazol-4-yl)-2-(carboxy ethenyl-8-oxo-5-thia-1-azabicyclo[4.2.0]oct-2-ene-2carboxylic acid.

Mol.Formula: $\mathrm{Cl}_{6} \mathrm{H}_{1} 5 \mathrm{~N}_{5} \mathrm{O}_{7} \mathrm{~S}_{2}$

Mol.Wt: $453.452 \mathrm{~g} / \mathrm{mol}$<smiles>C=CC1=C(C(=O)O)N2C(=O)[C@@H](NC(=O)/C(=N/OCC(=O)O)c3csc(N)n3)[C@H]2SC1</smiles>

\section{Structure of Cefixime}

Therapeutic category: Antibacterial

Cefixime is a broad spectrum cephalosporin antibiotic and is commonly used to treat susceptible infections, including gonorrhea, otitis media, pharyngitis, lower respiratory-tract infections such as bronchitis, and urinary-tract infections.

High Performance Liquid Chromatography (HPLC)

The modern form of column chromatography called high performance, high pressure, high resolution and high speed liquid chromatography. The equipment consists of an a high pressure, injector, eluent and reservoir, for introducing the sample, a column containing the stationary phase, a detector and recorder. The development of highly efficient micro particulate bonded phases has increased the versatility of the technique and has greatly improved the analysis of multi component mixtures.

\section{Gas Chromatography} methoxyimino)acetyl]amino $-3-$

Gas-liquid chromatography (GLC) is a common type of chromatography used in analytical chemistry for separating and analyzing compounds that can be vaporized without decomposition. Typical uses of GC include testing the purity of a particular substance or separating the different components of a mixture (the relative amounts of such components can also be determined). In some conditions, GC can help in identifying a compound. In beginning chromatography, GC can be used to prepare pure compounds from a mixture. The major factor in separation is due to analytes having different affinities for the stationary phase.

\section{Experimental Procedure}

Standard test procedure Solubility: The qualitative visual test for solubility has been included confirm that incoming batches of Cefixime drug substance specifications and it is based on Europe.

Cefixime is slightly soluble in water and soluble in methanol

Reagents:

1. Water

2. Methanol 


\section{Procedure}

Place $10 \mathrm{mg}$ of sample in $10 \mathrm{ml}$ of $\mathrm{H} 2 \mathrm{O}$; place 1 $\mathrm{gm}$ of sample in $30 \mathrm{ml}$ of methanol. Shake vigorously for 30 seconds at an interval of 5 minutes. Observe the solubility behaviour for 30 minutes. It is considered to be completely soluble, if none of the particles or droplet of the solute is observed.

\section{Identification}

a) Infrared Spectroscopy: Mix the sample with $\mathrm{KBr}$ to finely powdered and prepare the pellets by pressing the mixture in a die and identified by infrared absorption spectroscopy. If the spectra obtain show difference, dissolve the sample and Reference substance separately in $\mathrm{CH} 3 \mathrm{OH}$, evaporate to dryness and record the new spectra using the residues. Suspend $0.5 \mathrm{gm}$ of sample in $\mathrm{H} 20$ and dilute to $10 \mathrm{ml}$ with same solvent.

a) $\mathrm{pH}$ :

\section{OPTIMIZED METHOD}

Column: mm) C $18,4 p$

Flow rate: Novapak (150 mm x 3.9

Detection: $1 \mathrm{ml} / \mathrm{min}$

Column oven temp: $254 \mathrm{~nm}$ $\quad 10 \mathrm{pl}$ Run time: $\quad 20 \mathrm{~min}$

\section{Preparation of tetrabutyl ammonium hydroxide} solution: Dissolve $8.2 \mathrm{gm}$ of tetrabutyl ammonium hydroxide in $800 \mathrm{ml}$ of water. Adjust the $\mathrm{pH}$ to $6.5 \pm$ 0.05 with dilute phosphoric acid and dilute to $1000 \mathrm{ml}$ with water.

Preparation of Mobile phase: Mix 770ml of tetra butyl ammonium hydroxide solution with $230 \mathrm{ml}$ of acetonitrile and homogenize. Filter the solution through $0.45 \mathrm{p}$ membrane filter.

\section{Preparation of Diluent:}

Use mobile phase as diluent.

METHOD DEVELOPMENT FOR ASSAY Selection of diluent

Cefixime is freely soluble in water and methanol.

Mobile phase tetrabutyl ammonium hydroxide $\mathrm{pH} 6.5$ : acetonitrile 77:23 V/V was selected because of its more extraction efficiency with less base line disturbances.

\section{Selection of detector wave length}

Based on the spectrum obtained by $10 \mathrm{pg} / \mathrm{ml}$ sample of Cefixime in water. The absorption maxima $254 \mathrm{~nm}$ were selected as detector wavelength.

\section{Selection of mobile phase composition}

After screening of experiments by using different compositions of buffer and organic phases $\mathrm{pH} 6.5$ is selected. Mixture of tetrabutyl ammonium hydroxide and acetonitrile 77:23 V/V was selected due to low retention time and high plate count.

\section{Selection of column}

Novapak ( $150 \mathrm{~mm} \times 3.9 \mathrm{~mm}) \mathrm{C} 18,4 \mathrm{p}$ column is selected due to high stability at environmental $\mathrm{pH}$ and less retention time for Cefixime peak with good peak shape and high plate count.

\section{Fixing of flow rate and injection volume}

$1.0 \mathrm{ml} / \mathrm{min}$ was selected due to optimum retention time for cefixime with high plate count.

$10 \mathrm{pl}$ injection volume was fixed due to good peak shape of cefixime without distortion. Assay System suitability sample was injected before analysis. System suitability results indicate the suitability of chromatographic system for assay analysis.

\section{Preparation of Resolution solution}

Weigh and transfer about 10mg of cefixime working standard into a $10 \mathrm{ml}$ volumetric flask. Dilute to volume with water. Heat this solution on a water bath for $45 \mathrm{~min}$ and cool, filter the solution through $0.45 \mathrm{p}$ membrane filter.

Note: Use this solution promptly.

\section{Preparation of Standard solution}

Accurately weigh and transfer $50 \mathrm{mg}$ of cefixime working standard into a $50 \mathrm{ml}$ volumetric flask. Add 35 $\mathrm{ml}$ of diluent and sonicate to dissolve. Dissolve in and dilute to volume with diluent, filter the solution through $0.45 \mathrm{p}$ membrane filter.

\section{System suitability}

Inject $10 \mathrm{pl}$ of resolution solution into the chromatogram, using the given chromatographic parameters and record the peak responses.

1. The resolution between Cefixime E- isomer and cefixime peaks is NLT 2.0

2. The Retention time of cefixime E-isomer and cefixime peaks are around 9 and $10 \mathrm{~min}$, respectively.

3. The RSD of the areas of cefixime determined from Six replicate injections of Standard solution is NMT $1.0 \%$

\section{Preparation of Sample solution}

Accurately weigh and transfer about $50 \mathrm{mg}$ of sample to be analyzed into a $50 \mathrm{ml}$ volumetric flask. Add $35 \mathrm{ml}$ of diluents and sonicate to dissolve. Dilute to volume with diluent. Filter the solution through 0.45 p membrane filter.

\section{Procedure}

Seperately inject $10 \mathrm{pl}$ of sample solution in duplicate into the chromatograph record the chromatograms and measure the peak responses of cefixime. 


\section{Calculation}

Assay of Cefixime (\%w/w on an anhydrousbasis) where

AT $=$ Average of the area of the cefixime peak in the chromatogram obtained from the sample peak.

AS $=$ Average of the area of the cefixime peak in the chromatogram obtained from the standard peak.

$\mathrm{WS}=$ Weight of the standard in $\mathrm{mg}$.

$\mathrm{WT}=$ Weight of the sample in $\mathrm{mg}$.

$\mathrm{P}=$ Purity of the cefixime working standard $(\% \mathrm{~W} / \mathrm{W}$ on as is basis)

$\mathrm{Z}=\mathrm{Water}$ content of the sample (\% W/W by KF)

\section{Results and Discussion \\ Description}

The given sample Cefixime was observed as Almost White owder and slightly hygroscopic.

Solubility: The given sample cefixime was Slightly soluble in water, soluble in methanol.

\section{Graph 1: Spectrum of Both Standard and Sample Cefixime}

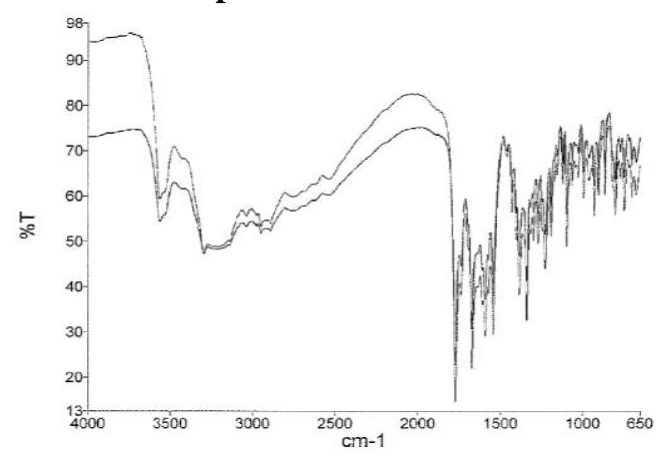

Graph 2: IR spectrum of pooled sample Ceflxime

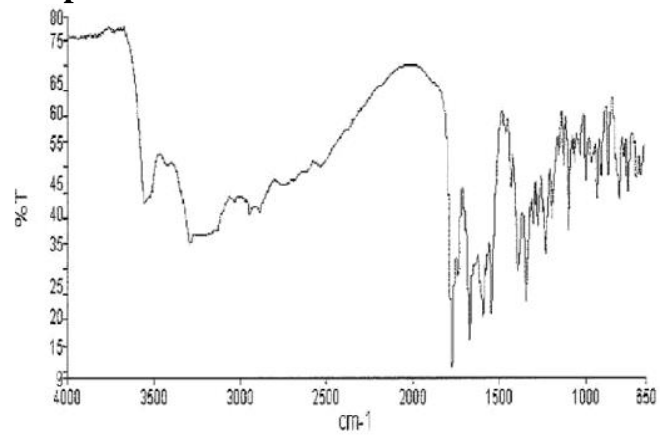

\section{Identification}

Table 1: Peak and intensity of Standard Ceflxime

\begin{tabular}{|c|c|c|}
\hline Peak Name & $\mathbf{X}$ & $\mathbf{Y}$ \\
\hline 10 & 1225.83 & 51.99 \\
\hline 9 & 1337.56 & 42.67 \\
\hline 8 & 1384.17 & 48.1 \\
\hline 7 & 1542.03 & 39.91 \\
\hline 6 & 1569.88 & 47.72 \\
\hline 5 & 1591.53 & 39.24 \\
\hline 4 & 1669.97 & 33.41 \\
\hline 3 & 1737.26 & 47.87 \\
\hline 2 & 1771.89 & 26.08 \\
\hline 1 & 3295.75 & 54.03 \\
\hline
\end{tabular}




\section{Graph 3: IR spectrum of pooled sample Ceflxime}

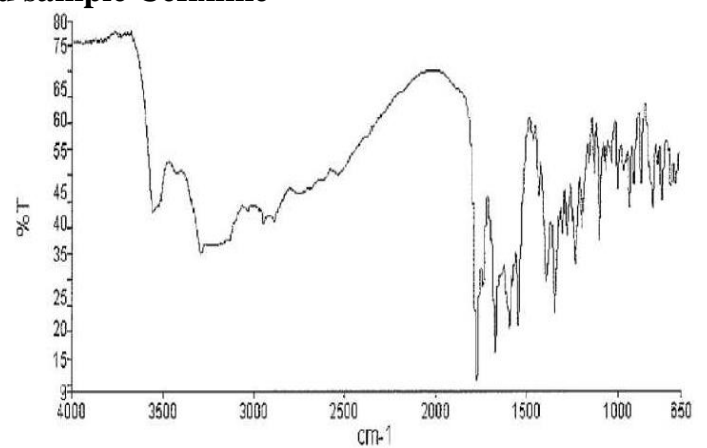

Table 2: Peak and intensity of Cefixime Sample

\begin{tabular}{|c|c|c|}
\hline Peak Name & X & Y \\
\hline 10 & 1225.72 & 33.11 \\
\hline 9 & 1337.46 & 23.71 \\
\hline 8 & 1383.86 & 29.82 \\
\hline 7 & 1541.92 & 21.33 \\
\hline 6 & 1569.96 & 29.14 \\
\hline 5 & 1591.54 & 20.73 \\
\hline 4 & 1670.32 & 15.84 \\
\hline 3 & 1737.26 & 28.89 \\
\hline 2 & 1771.9 & 10.46 \\
\hline 1 & 3296.11 & 53.83 \\
\hline
\end{tabular}

Identification of Cefixime by Assay Technique

Assay is the potency of the drug, this test reveals that \% of assay of given Cefixime sample using Cefixime standard 0.050 - ]

0.040

0.030

0.020

$0.010-$

0.000-j

2.00

400

$6.00 \quad 8.00$

10.00

$\begin{array}{lll}12100 & 14.00 \quad 16.00\end{array}$

$1800 \quad 20 . \mathrm{C}$

\section{Blank Solution of Cefixime}

Graph 4: Resolution chromatogram of Cefixime

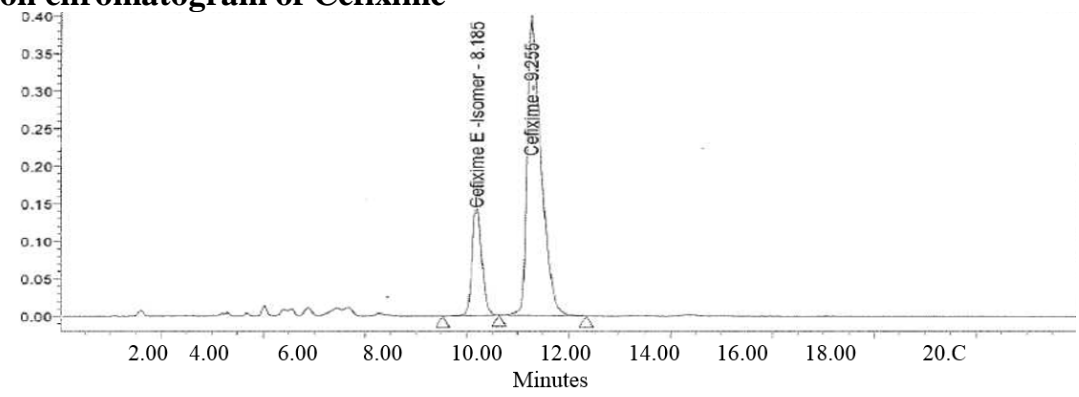

\section{System Suitability}

1. The resolution between Cefixime E- isomer and cefixime peaks is 1.2.

The Retention time of standard cefixime peak is 9 . 
Graph 5: Trail 1 Chromatogram for Ceflxime Sample

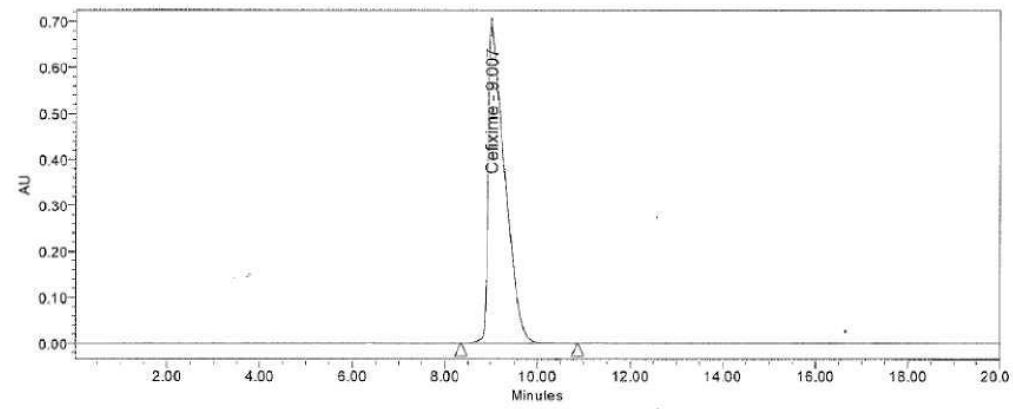

Table 3: Results for Trial 1 Ceflxime sample

\begin{tabular}{|c|c|c|c|c|c|}
\hline & Name & RT & Area $\left({ }^{\wedge} \mathbf{V} * \mathbf{s e c}\right)$ & \% Area & IntType \\
\hline 1 & Cefixime & 9.007 & 17142521 & 100.00 & BB \\
\hline
\end{tabular}

Graph 6: Trail 2 Chromatogram for Cefixime Sample

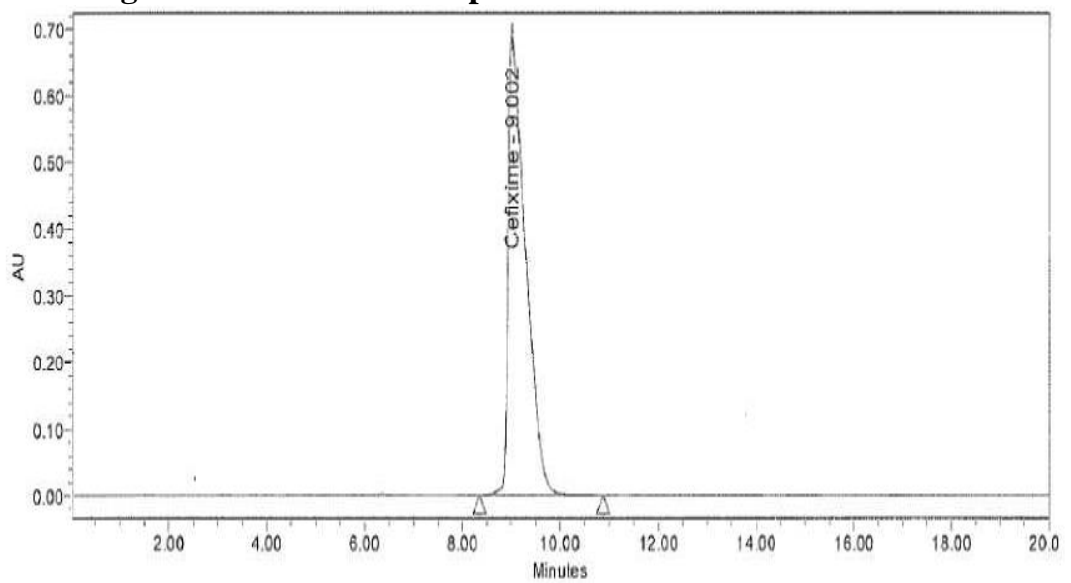

Table 4

\begin{tabular}{|c|c|c|c|c|c|}
\hline & Name & RT & Area $\left({ }^{\wedge} \mathbf{V}^{*}\right.$ sec $)$ & \% Area & IntType \\
\hline 1 & Cefixime & 9.002 & 17148319 & 100.00 & BB \\
\hline
\end{tabular}

The assay of given Cefixime sample was calculated

AT WS $\mathbf{5 0}$

100

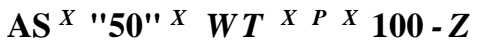

The potency of the given sample is $=99.79 \%$ 


\section{Method Validation}

Chromatogram of Specificity:

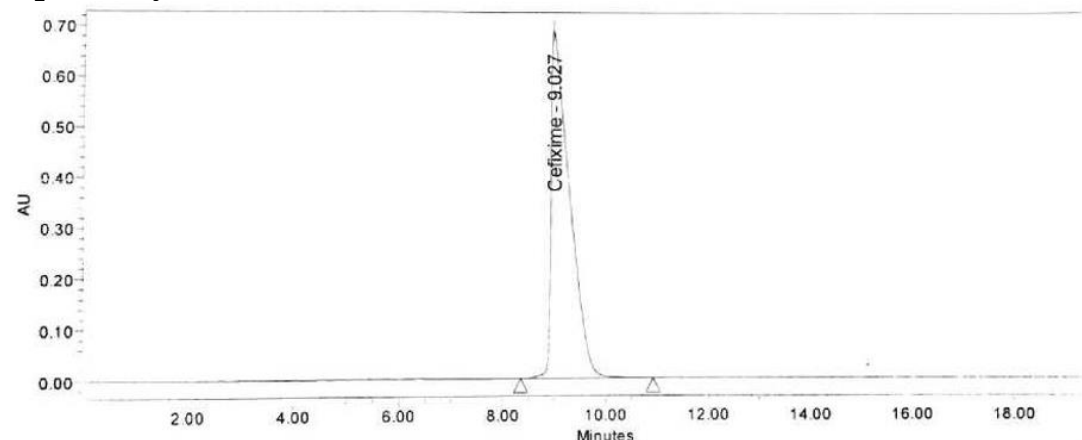

Fig. 1: Chromatogram for Standard

Table 5: Data of specificity

\begin{tabular}{|l|c|c|c|c|c|}
\hline \multicolumn{1}{|c|}{ S.No } & Name & $\begin{array}{c}\text { Retention } \\
\text { time }\end{array}$ & Area & $\begin{array}{c}\text { USP plate } \\
\text { count }\end{array}$ & USP tailing \\
\hline Standard & Cefixime & 9.027 & 17312296 & 4198 & 1.46 \\
\hline Sample & Cefixime & 9.007 & 17142521 & 4518 & 1.47 \\
\hline
\end{tabular}

\section{Inference}

The $\mathrm{R}_{\mathrm{t}}$ of standard and test sample was found to be almost equal. Hence the method is specific for estimation of Cefixime.

\section{Accuracy}

Table 6: Data of accuracy

\begin{tabular}{|c|c|c|c|c|}
\hline & Accuracy & $\begin{array}{c}\text { Amount added } \\
(\mathbf{p g})\end{array}$ & \% recovery & Mean recovery \\
\hline 1. & $80 \%$ & 80 & 98.95 & MEAN=99.93 \\
\hline 2. & $80 \%$ & 80 & 99.90 & S.D $=0.81$ \\
\hline 3. & $80 \%$ & 80 & 100.95 & $\%$ RSD $=0.81$ \\
\hline 4. & $100 \%$ & 100 & 99.20 & MEAN=99.14 \\
\hline 5. & $100 \%$ & 100 & 98.89 & S.D $=0.18$ \\
\hline 6. & $100 \%$ & 100 & 99.34 & $\%$ RSD $=0.18$ \\
\hline 7. & $120 \%$ & 120 & 99.23 & MEAN=99.28 \\
\hline 8. & $120 \%$ & 120 & 99.21 & S.D $=0.08$ \\
\hline 9. & $120 \%$ & 120 & 99.40 & $\%$ RSD $=0.08$ \\
\hline
\end{tabular}

6 Chromatogram of Specificity:

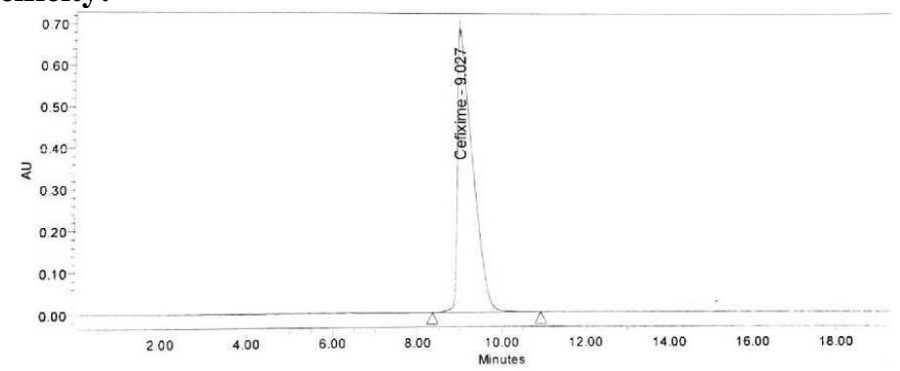


Fig. 2: Chromatogram for Standard

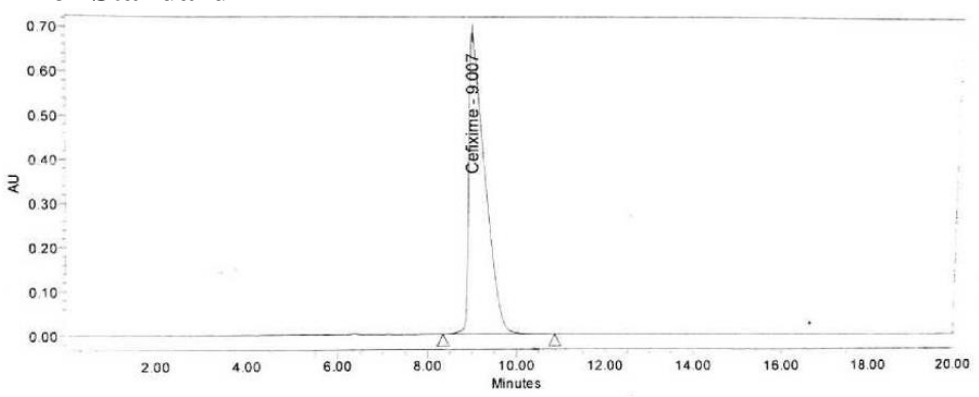

\section{Chromatogram for sample}

\section{Chromatogram: 1}

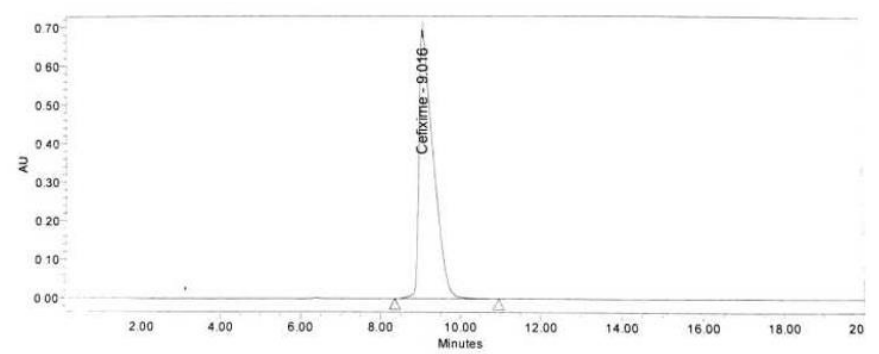

Chromatogram: 2

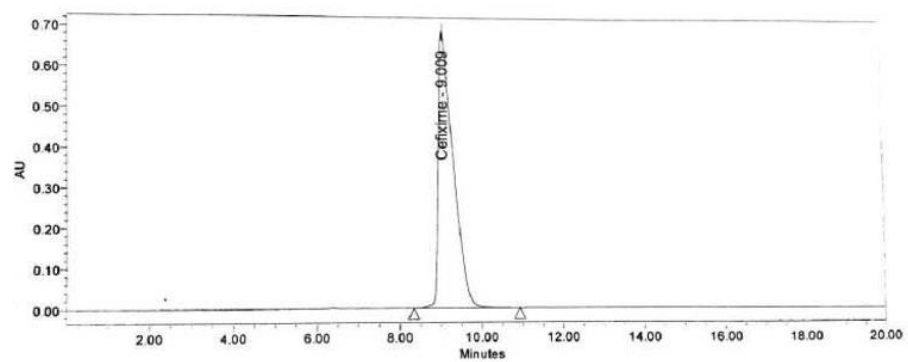

\section{Chromatogram: 3}

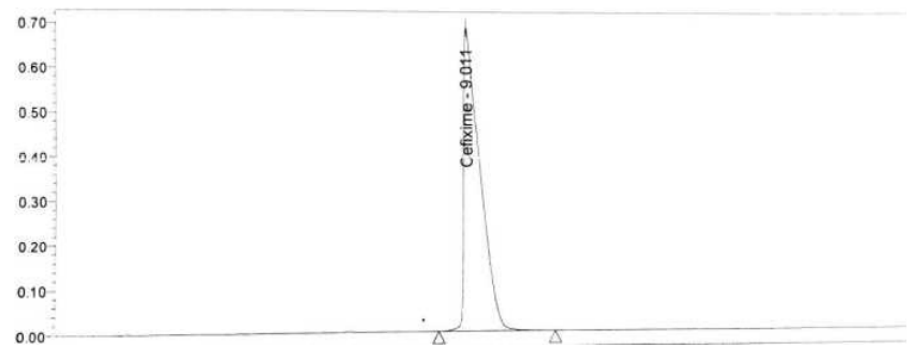

Chromatogram: 4

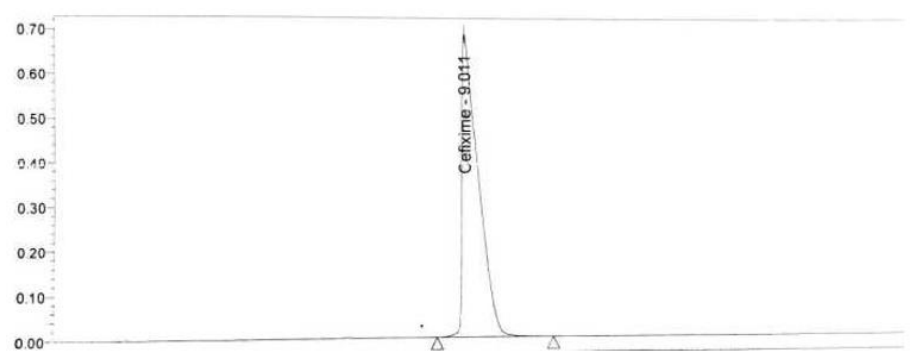




\section{Chromatogram: 5}

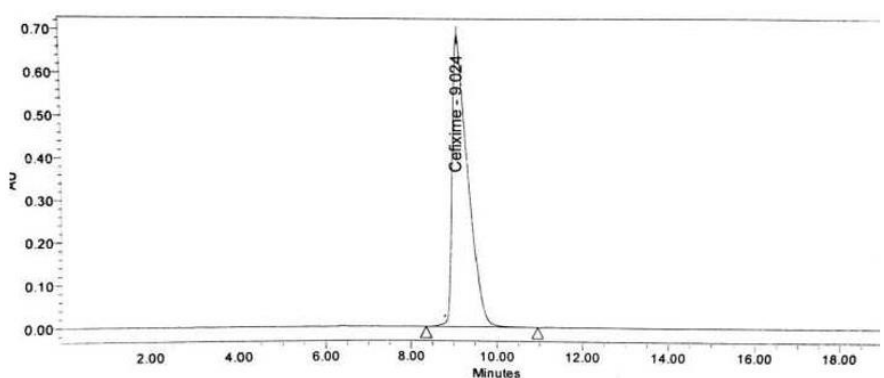

Chromatogram: 6

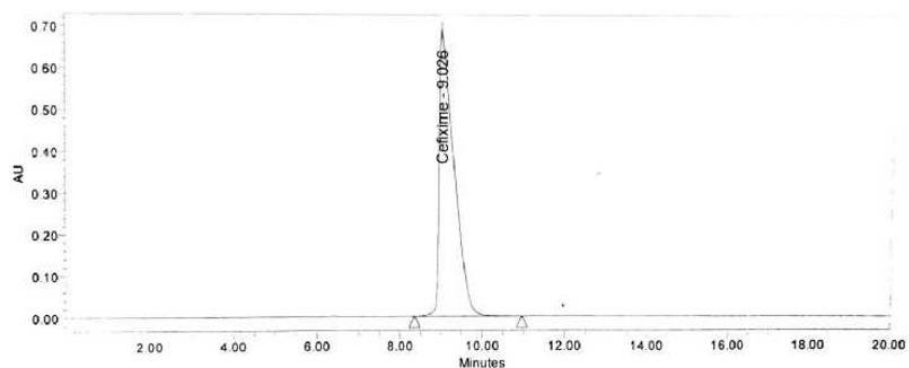

\section{Chromatogram: 7}

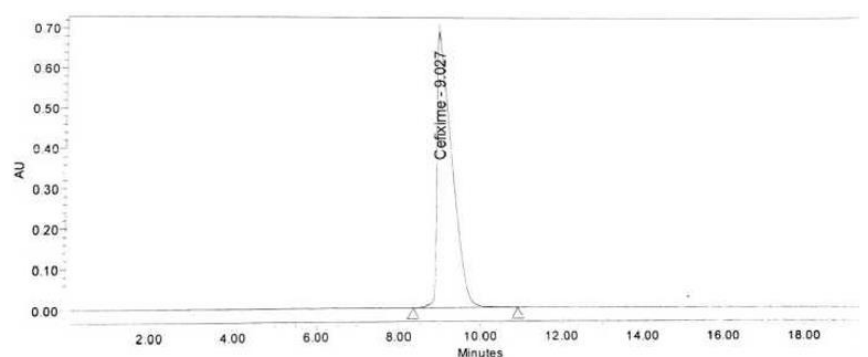

Table 7: Data of chromatograms of system precision

\begin{tabular}{|l|c|c|}
\hline Injection (100 pg/ml) & Retention time & Area \\
\hline Injection-1 & 9.016 & 17301531 \\
\hline Injection-2 & 9.009 & 17269092 \\
\hline Injection-3 & 9.011 & 17304495 \\
\hline Injection-4 & 9.024 & 17271267 \\
\hline Injection-5 & 9.026 & 17272472 \\
\hline Injection 6 & 9.027 & 17312296 \\
\hline Average & & 17288525.5 \\
\hline Standard deviation & & 17899.88 \\
\hline \% RSD & & 0.10 \\
\hline
\end{tabular}

\section{Chromatogram of method precision}

\section{Chromatogram: 1}

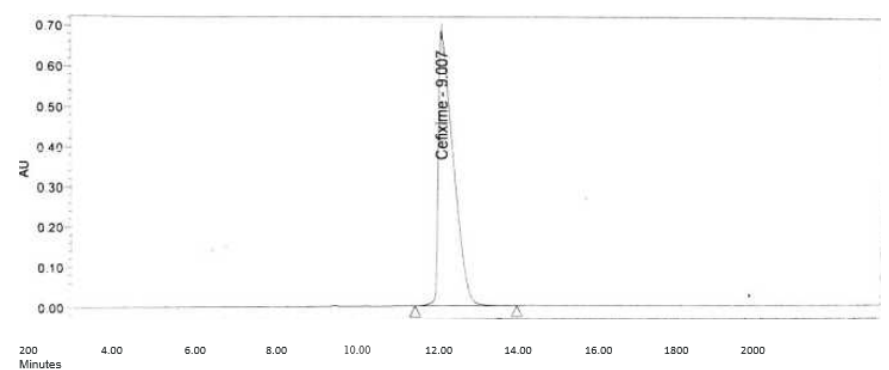




\section{Chromatogram: 2}

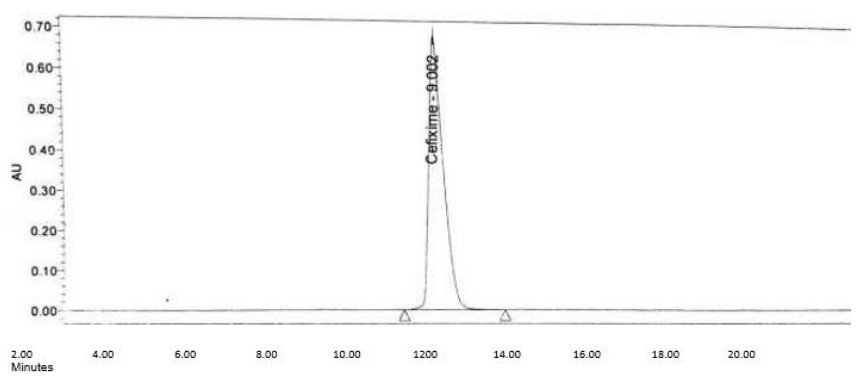

\section{Chromatogram: 3}

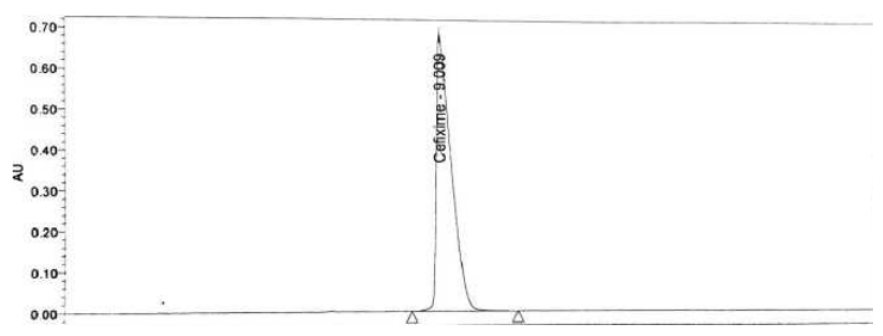

\section{Chromatogram: 4}

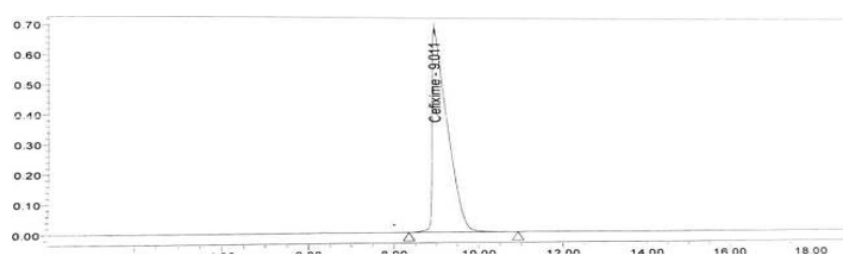

\section{Chromatogram: 5}

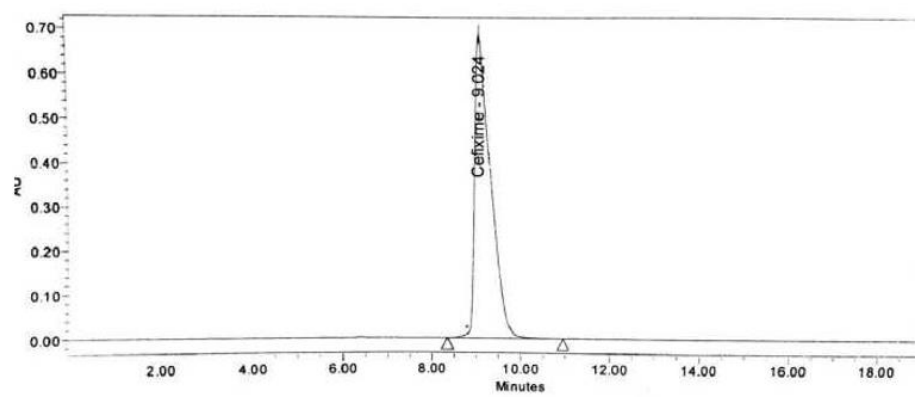

\section{Chromatogram: 6}

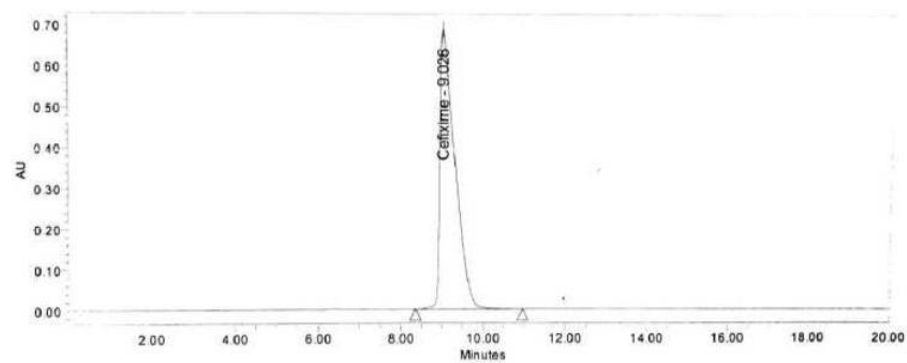

\section{Summary and Conclusion}

The antibiotic of Cefixime was subjected to both physical and chemical tests. The various tests like Description, Solubility, Identification, Water content, Assay, Related substances, Residual solvents has been performed for Cefixime.

Identification test was performed by using Infrared Spectroscopy and High performance Liquid Chromatography (HPLC) techniques.

For routine analytical purpose it is desirable to 
establish methods capable of analyzing huge number of samples in a short time period with good robust, accuracy and precision without any prior separation step.

HPLC \& GC methods generate large amount of quality data which serve as highly powerful and convenient analytical tool.

Assay and Related substances were performed by using HPLC technique.

Based on literature review, a HPLC method was developed on Novapak $\mathrm{C}_{18}(150 \mathrm{~mm}$ x $3.9 \mathrm{~mm}, 4 \mathrm{pm}$ particle size) column with tetrabutyl ammonium hydroxide and acetonitrile $(77: 23, \mathrm{~V} / \mathrm{V})$ as mobile phase at a flow rate of $1.0 \mathrm{ml} / \mathrm{min}$ with UV detection at $254 \mathrm{~nm}$ for estimation of Cefixime. The run time of the HPLC procedure is only 20 minutes. The Proposed RPHPLC method was suitable technique for estimation of milnacipran hydrochloride in pharmaceutical dosage form without any interference from other excipients.

All the parameters for drug had met the criteria of ICH guidelines for method validation. The developed method may be recommended for routine and QC analysis of investigational drugs to provide simple, accurate and reproducible quantitative analysis. The \% RSD of proposed method was found to be less than $2 \%$ shows its capacity to remain unaffected by small, but deliberate variations in method parameters and provides an indication of its reliability during normal usage. The low values of \% RSD indicate the method is precise and accurate.

\section{References}

1. Sharma BK, Instrumental methods of chemical analysis, $19^{\text {th }}$ Edition. Meerut: Goel Publishing House, 2000:1-4.

2. Skoog W, Fundamental of Analytical Chemistry, Saunders College, Publishing, $7^{\text {th }}$ Ed. 1992:1-3.

3. Beckett AH, Stenlake JB, Practical pharmaceutical chemistry, part -II. $4^{\text {th }}$ Edition. New Delhi, CBS Publishers 1997:293-304.

4. Michael E, Schartz IS, Krull, Analytical method development and validation 1997:25-46.

5. Kasture A.V, Wadodkar S.G, Mahadik K.R, and More H.N, Textbook of Pharmaceutical Analysis - II, Published by NiraliPrakashan, 13th Edition, 2005:47-56.

6. Cai J, Xing Y, Yang M, Zhao X, Preparation of modified $\mathrm{y}$-alumina as stationary phase in gas-solid chromatography and its separation performance for hydrogen isotopes Adsorption. 2013(14). doi:10.007/s10450-013-9499-2.

7. Boutagy J, Detection and analysis of adenine arabinoside by gas-liquid chromatography using a nitrogen sensitive detector, Br J Clin Phamacol 2012;5(1):86-9.

8. Jean-Pierre CL, Lesley A. Elizabeth S, Turrella, Quilliamb MA. Solid-phase extraction and liquid chromatography-mass spectrometry for the determination of free fatty acids in shellfish, J. Chromatogr. A. 2007(23);1145(1-2):51-7.

9. Hill, Collin, Flockhart, Applications of liquid-liquid chromatography Instrumentation for laboratory preparative and process chemistry. Chromatography Today 2009;16-9.

10. Braithwaite A and Smith F. J, Chromatographic methods, $5^{\text {th }}$ Edition, 1999:262266.
11. Beckett A.H, Stenlake J.B., Practical Pharmaceutical chemistry, CBS publishers and distributers, New Delhi, $4^{\text {th }}$ Edition, Part 2, 2007:72-73,85,275-277,379.

12. Snyder LR., Kirkland JJ, Joseph LG., Practical HPLC method development $2^{\text {nd }}$ Edition, New York, John wiley and sons; 1997. P 46-51.

13 Chatwal R, Anand S. Instrumental methods of chemical analysis, Himalaya publishing house, $5^{\text {th }}$ Edition, 2002, P. 2.566-2.567.

14. David G. Watson. Pharmaceutical analysis, Harcourt Publishers house, 1999:248-50.

15. Asian guidelines for validation of analytical procedures, adopted from ICH guidelines, ICH Q2A/Q2B.

16. Kateman $\mathrm{G}$ and Buydens L, Quality control in analytical chemistry, $2^{\text {nd }}$ Edition, wiley, New York, 1994:118-25.

17. Skoog, Principles of instrumental analysis, $8^{\text {th }}$ Edition, Thomson brooks/Cole 2007:169-73.

18. Lloyd R. Snyder, Joseph J. Kirkland, Joseph L. Glajch, Practical HPLC method development, $2^{\text {nd }}$ Edition, 1-8.

19. SatinderAhuja, Michael W.Dong, Handbook of pharmaceutical analysis by HPLC, vol 6, Elseivier (2009) 22-23.

20. The United States pharmacopoeia - 32(2009), National formulary 27, US Pharmacopoeial convention Inc., Rockville, 1956-7.

21. ICH guidelines Q2A, Validation of Analytical procedures: Definition and terminology Geneva, Switzerland 1995;68-76.

22. George N, Forced degradation as an integral part of HPLC stability-indicating method development, drug delivery technology, 2010;10(5).

23. Reynolds D.W, Facchine K.L, Mullaney J.F, Alsante K.M, Hatajik T.D, Motto M.G, Available guidance and best practices for conducting forced degradation studies, Pharmaceutical technology, 2002;48-56.

24. Ahuja,S.;Mills,K.; Handbook of isolation and characterization of impurities in pharmaceuticals, 1 st ed.; Elsevier: California, 2003 